\title{
Drought acclimation in field growing subterranean clover plants
}

\author{
FX Socias ${ }^{\dagger}, \mathrm{H}$ Medrano* \\ Lab de Fisiología Vegetal, Dept de Biología Ambiental, Institut d'Estudis Avançats-Universitat de les Illes Balears, \\ E07071 Palma de Mallorca, Spain
}

(Received 7 July 1993; accepted 3 January 94)

\begin{abstract}
Summary - The slow-induced drought response of subterranean clover plants was studied under field conditions. Soil and plant water status, leaf growth and photosynthetic characteristics were determined in simulated microswards with irrigation and with withholding watering. In response to soil water depletion, stomatal conductance was quickly reduced to $50 \%$ of controls without any significant change in water relation, later achieving extremely low values $\left(0.1 \mathrm{~mol} \mathrm{~m}^{-2} \mathrm{~s}^{-1}\right)$. The evaporation rate was also reduced to $35-40 \%$ of irrigated plants, but the photosynthesis rate remained at $50 \%$. A steep drop in water relations as well as leaf size and specific leaf dry weight was apparent by the 32nd day of water stress in the first group of mature leaves fully developed under drought. An osmotic adjustment in response to soil water depletion was clear. The reduction in leaf appearance rate as well as in single leaf area effectively contributed to the increase in water economy in the canopy.
\end{abstract}

water stress/leaf water potential/osmotic adjustment/ $\mathrm{CO}_{2}$ assimilation rate/acclimation

Résumé - Acclimatation à la sécheresse chez les plantes de trèfle souterrain cultivées au champ. L'acclimatation à une sécheresse progressive a été étudiée au champ. L'état hydrique des plantes et du sol, la croissance des feuilles et les paramètres de la photosynthèse ont été déterminés dans 2 petites parcelles, l'une irriguée, l'autre pas. En réponse à la disparition de l'eau dans le sol, la conductance stomatique a diminué rapidement jusqu'à $50 \%$ du témoin, sans variation dans les relations hydriques, pour arriver à de très basses valeurs $\left(0,1 \mathrm{~mol} \mathrm{~m}^{-2} \mathrm{~s}^{-1}\right)$. En conséquence, la vitesse d'évaporation a été réduite de 35 à $40 \%$ de celle des plantes irriguées, et le taux de photosynthèse est resté à $50 \%$. Les relations hydriques ont fortement diminué, ainsi que la taille des feuilles et leur poids sec spécifique au $32^{e}$ jour de la sécheresse: ces feuilles s'étaient entièrement développées pendant la période de sécheresse. Un ajustement osmotique s'est produit en réponse à la diminution de l'eau dans le sol. La réduction de la vitesse d'apparition des feuilles a contribué à ajuster l'économie hydrique dans les plantes.

stress hydrique/potentiel hydrique des feuilles/ajustement osmotique/vitesse d'assimilation du CO acclimatation

\section{INTRODUCTION}

Soil water deficit is the main limiting factor of forage crops in drought prone areas (Muslera and Ratera, 1991). Subterranean clover is a widely distributed annual, self-reseeding pasture in Mediterranean zones. It growth period from September to June is outside the drier season, but long drought periods are often prevalent during autumn and spring months seriously reducing the herbage production (McGuire, 1985). These yield limitations will become even stronger according to

\footnotetext{
* Correspondence and reprints.

† This paper was finished after the first author FX Socias disappeared on the Dirham Peak. In memoriam.

Abbreviations. SWC: soil water content; SFW: soil fresh weight; SDW: soil dry weight; SLDM: specific leaf dry weight;

VPD: vapor pressure deficit.
} 
the climate change predictions, and a better knowledge of the whole plant response to soil water depletion is needed for the improvement of management practices as well as for breeding programs for drought resistance in these areas.

In response to water stress, different morphological and physiological acclimation responses are induced in the plant, which in turn improve the plant ability to offset the damage of water deficit. These acclimatation responses have been described as particular combinations of morphological and physiological modifications named plant strategies according to Levitt (1972) and Ludlow (1989).

However, the specific pattern of the plant response to soil water depletion is also dependent on the environmental conditions under which such stress develops, particularly irradiation and vapor pressure deficit (Schulze, 1986; Sharp and Davies, 1989) as well as on the duraction and intensity of soil water depletion (Dale, 1988). For instance, the osmotic adjustment is greater when the rate of soil water depletion is slower (Morgan, 1984).

Stomatal closure is a quicker and more flexible process than changes in root growth, leaf area or life cycle. In fact, a significant decrease in stomatal conductance is observed early in response to soil drying, even before any noticeable leaf water potential reduction (Davies and Zhang, 1991). This quick stomatal response seems to be mediated by a non-hydric, chemical signal (ABA) which originates from dehydrating roots and is transported to the leaves through the transpiration stream (Davies and Zang, 1991). However, it has recently been demonstrated that the stomatal sensitivity to $A B A$ is also dependent on the leaf water status (Tardieu and Davies, 1992, 1993). This could especially apply in long-term drought periods in which water potential is gradually reduced to extremely low values.

An immediate effect of stomatal closure is the limitation of water loss, but, in time, carbon flux to mesophyll is reduced, and, in a long-term response, mesophyll capacity for carbon uptake could also be diminished (Gimenez et al, 1992).

For long-term sustained drought developed under field conditions, therefore plant response to soil drying will be difficult to predict from laboratory experiments. This is particularly important when agronomic applications are to be derived from the study of plant response.

In previous work (Medrano et al, 1992), the effect of gradual and rapidly induced soil water depletion was compared in subterranean clover plants growing in pots under different environmental conditions. When drought was gradually imposed, plant response was demonstrated to show particular characteristics clearly different from a typical water-withholding procedure, which allowed a significant improvement in final water-use efficiency.

In the present work, the objective was to study the subterranean clover response to soil drying under more realistic conditions, in a field-developed microsward assay, in order to achieve a first evaluation of the acclimation pattern as well as of the plant characteristics contributing to improving plant resistance to drought.

\section{MATERIALS AND METHODS}

\section{Plant culture}

Subterranean clover (Trifolium subterraneum ssp brachycalycinum cv Clare) seeds were sown in small pots with a commercial horticulture substrate (January 10, 1992). Two weeks after germination, plantlets were planted in the field, on a clay-calcareous soil in Palma de Mallorca (Spain) in 6 simulated pasture plots of $0.5 \times 0.5 \mathrm{~m}(250$ plants $\mathrm{m}^{-2}$ ). Before planting, the experimental area was fertilized with $15 \mathrm{~g} \mathrm{~N} \mathrm{~m}^{-2}, 6.1 \mathrm{~g} \mathrm{P} \mathrm{m}^{-2}$ and $5.8 \mathrm{~g} \mathrm{~K} \mathrm{~m}^{-2}$. Crop emergence and growth were satisfactory so that additional fertilization was not needed.

The experiment started when the plants completely covered the ground (March 20, 1992). Water stress was imposed on 3 adjacent plots by withholding watering from this date. Control treatment was maintained at field capacity by irrigation with a micro-sprinkler system as well as by occasional rain (a total of $86 \mathrm{~mm}$ during experiment). A plastic cover was placed over the water-stress plots when rainfall was expected, but immediately removed after the rain stopped. Sampling dates were $23 / 3,2 / 4,14 / 4,21.4,28 / 4$ and $7 / 5$ in 1992 . For each sampling time, predawn leaf water potential was measured the day following gas-exchange measurements and leaf sampling. For each of the measured characteristics, 6 different leaves per treatment ( 2 per plot) were sampled. 


\section{Soil and plant water status}

Soil water content (SWC) was measured at 10$15 \mathrm{~cm}$ depth and was calculated as follows:

SWC $=100($ SFW - SDW $) /$ SDW where SFW and SDW are fresh and dry weight of soil samples. Leaf relative water content (RWC) was measured at midday on recent fully expanded leaves and calculated according to Beadle et al (1985): $R W C=100(F W-D W) /(T W / D W)$, where FW, DW and TW are fresh, dry and turgid weight of the sampled leaf.

Leaf water potential $(\Psi)$ was determined at predawn conditions, with a Schölander pressure chamber (Soil Moisture Equipment Corp, CA), according to Faiz (1983). Leaves were frozen in liquid nitrogen and osmotic potential $\left(\Psi_{\pi}\right)$ was measured by using a vapor pressure osmometer (Wescor-5500). Turgor potential $\left(\Psi_{p}\right)$ was calculated from the difference between $\Psi$ and $\Psi_{\pi}$.

For protein determination, the youngest fully expanded leaves were rapidly frozen in liquid nitrogen and then lyophilized and stored dessicated at room temperature until analysis by the acid-ninhidrin method of Bates et al (1973).

\section{Leaf characteristics and development}

Before the treatment, 6 stems per plot were marked and the number of leaves was recorded several times during the experiment. The increase in the number of leaves per stem during a time period (ie the slope of number of leaves per stem versus number of days) represents the leaf appearance rate. Leaf area was always measured on youngest fully expanded leaves (3rd leaf of the stem) with a leaf area meter ( $\Delta \mathrm{T}$-Devices). Specific leaf dry mass (SLDM) was calculated by the ratio between leaf dry mass and leaf area.

\section{Gas-exchange measurements}

Measurements were made on single leaves, with a portable gas exchange system (Li-Cor, LI-6200 portable photosynthesis system, Lincoln, NE) using a $0.25 \mathrm{~L}$ chamber, in the closed-circuit mode. Leaf and chamber-air temperatures, humidity, and photosynthetic photon flux density (PPFD) were recorded during the measurements.
Internal $\mathrm{CO}_{2}$ concentration $\left(\mathrm{C}_{i}\right)$ was calculated from stomatal conductance to water vapor $(\mathrm{g})$ and $\mathrm{CO}_{2}$ assimilation rate $(\mathrm{A})$ values according to Farquhar and Sharkey (1982).

All measurements were taken on attached, recent fully expanded leaves of the top of the canopy. Samples were taken at midday on sunny days. The PPFD reached 1900 to $2100 \mu \mathrm{mol}$ photons $\mathrm{m}^{-2} \mathrm{~s}^{-1}$.

\section{RESULTS}

Average minimal and maximal temperatures during the experiment as well as midday relative humidity (table I) were typical of those during spring in Mediterranean conditions and they were in the optimal range for subterranean clover growth during all the experiment (McGuire, 1985).

\section{Soil and leaf water relationships}

Soil water content (fig 1) at $10-15 \mathrm{~cm}$ depth was maintained near field capacity $(-25 \%$ of SWC) for the control treatment during all the experiment. At this depth, subterranean

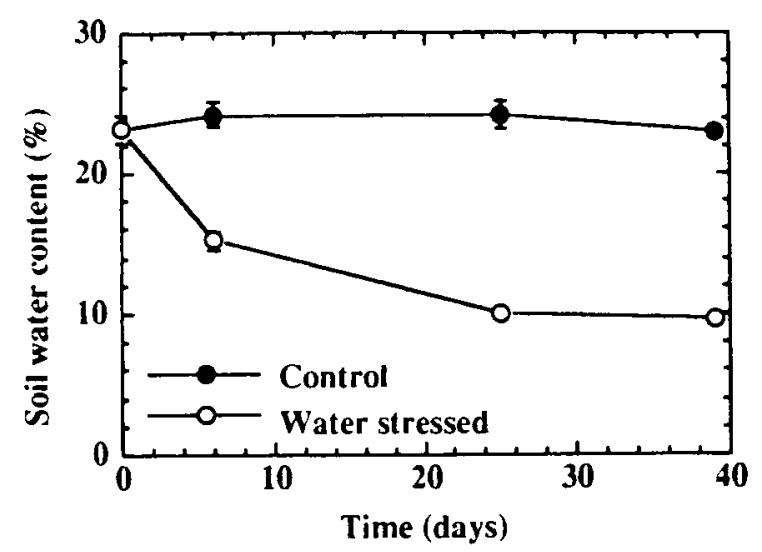

Fig 1. Soil water content during the experiment (between $10-15 \mathrm{~cm}$ depth). Vertical bars are \pm standard error.

Table I. Average minimal (Tmin) and maximal (Tmax) temperatures, and relative humidity RH between sampling dates.

Days of treatment

\begin{tabular}{lcccccc} 
& $0-3$ & $4-13$ & $14-25$ & $26-32$ & $33-39$ & $40-48$ \\
\hline $\mathrm{T} \min \left({ }^{\circ} \mathrm{C}\right)$ & $11.5 \pm 0.8$ & $9.2 \pm 0.7$ & $10.3 \pm 0.5$ & $9.6 \pm 0.7$ & $11.9 \pm 0.4$ & $13.8 \pm 0.4$ \\
$\mathrm{~T} \max \left({ }^{\circ} \mathrm{C}\right)$ & $19.5 \pm 1.1$ & $15.6 \pm 0.6$ & $16.6 \pm 0.8$ & $18.7 \pm 1.0$ & $21.1 \pm 0.5$ & $20.7 \pm 1.2$ \\
$\mathrm{RH}(\%)$ & $80.0 \pm 7.0$ & $79.2 \pm 2.6$ & $64.3 \pm 7.0$ & $58.4 \pm 4.5$ & $57.3 \pm 1.3$ & $64.5 \pm 3.8$ \\
\hline
\end{tabular}


clover develops the most important root extension. Nevertheless and especially in water-stressed plants, the roots could reach lower levels in the soil profile. For waterstressed plants, SWC showed an initial drop during the first $10 \mathrm{~d}$ of treatment and then a gradual decline until values closer to the wilting point $(-8 \%$ of $S W C)$ were reached.

For RWC determinations, as for all the measured parameters, sampled leaves were always the last fully expanded leaves of the top of the canopy, which, for subterranean clover, means the 3 rd leaf of the stems. Because new leaves appear continuously all along the growth period (see fig 6B below), at each sampling the fully expanded leaves were a new group of leaves.

The relative water content (fig 2) was clearly reduced in response to soil water depletion showing an early differentiation between treatments. There was a gradual decrease $(10 \%$ of control) until $d 30$, followed by a rapid drop (to values $17 \%$ lower than control) at the end of the experiment. Similar but more pronounced behavior was detected for the leaf water potential (fig 3A). The $\Psi$ depletion was about $38 \%$ of control treatment at $\mathrm{d} 30$, but reached $87 \%$ for the leaves sampled on d 39. Osmotic potential (fig 3B) as water potential maintained higher values for the control treatment during all the experiment but showed a slow sustained decline which could be related to the higher water demand due to both the progressive canopy development and the increasing irradiation and vapor pressure deficit.

Unirrigated plants showed a low but significant decline in $\Psi_{\pi}$ during the first weeks of

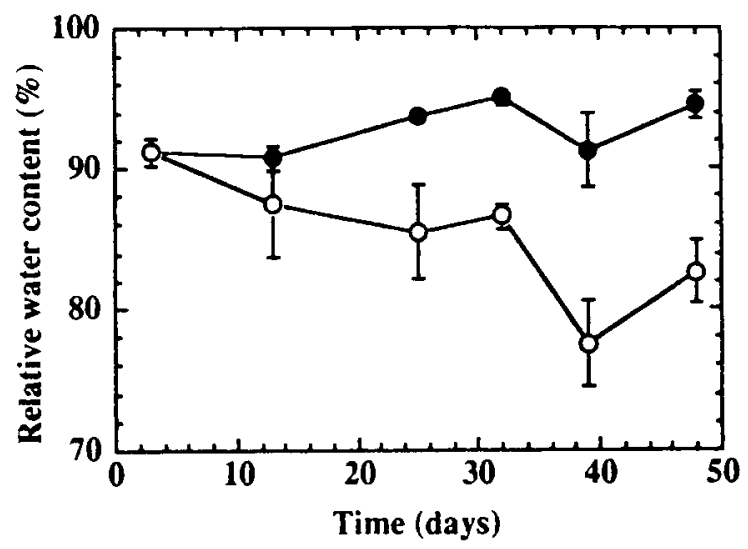

Fig 2. Leaf relative water content during the experiment ( : control; $O$ : water stressed).

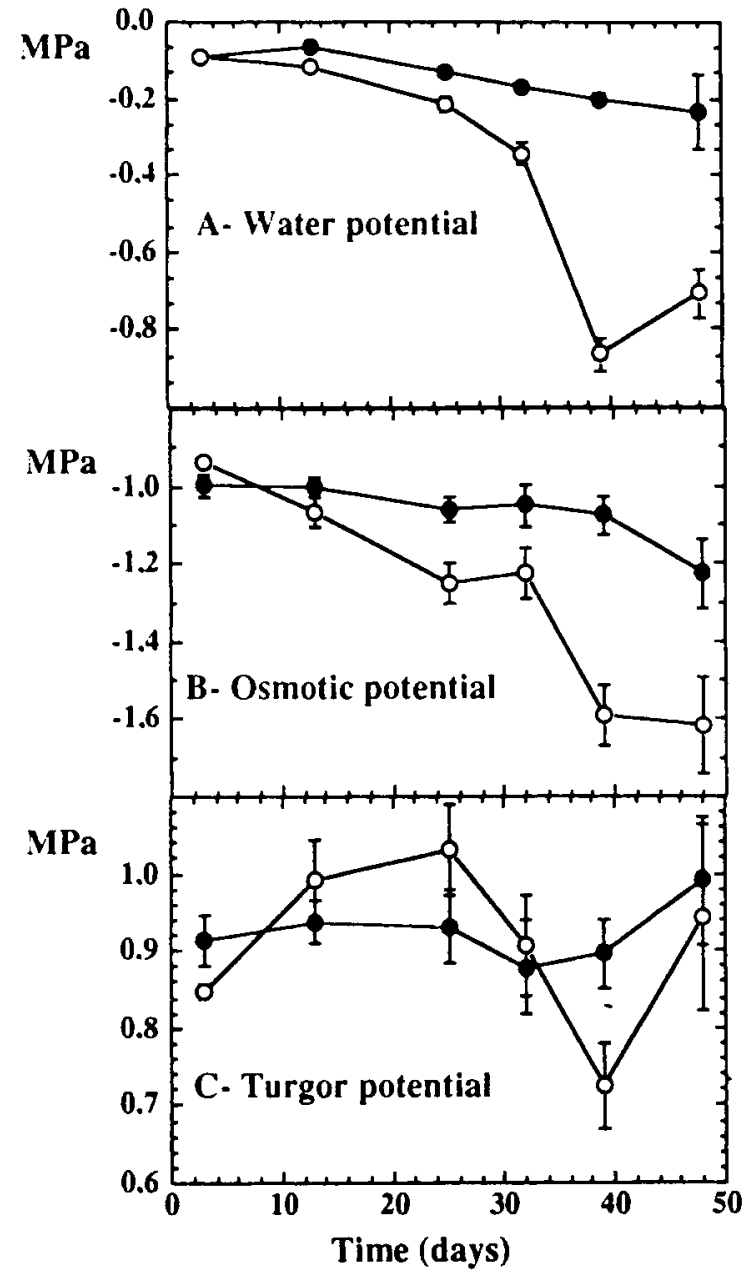

Fig 3. Leaf water status ( : control; $O$ : water stressed). Temporary pattern of leaf water potential components

treatment in which turgor potential for waterstressed plants was maintained even a little higher than for control plants (fig $3 \mathrm{C}$ ). At the end of the experiment, sampled leaves showed a much lower $\Psi_{\pi}$ in coincidence with $\Psi$ but this was not enough to prevent the $\Psi_{\mathrm{p}}$ falling to values significantly lower than the control.

The osmotic adjustment of water-stressed plants was evident and this corresponded with the progressive increase in the concentration of proline in water-stressed plants (fig 4).

\section{Leaf development}

Specific leaf dry mass of control plants (fig 5) showed small variations until $d 32$. Thereafter, there was a steep increase that could be re- 


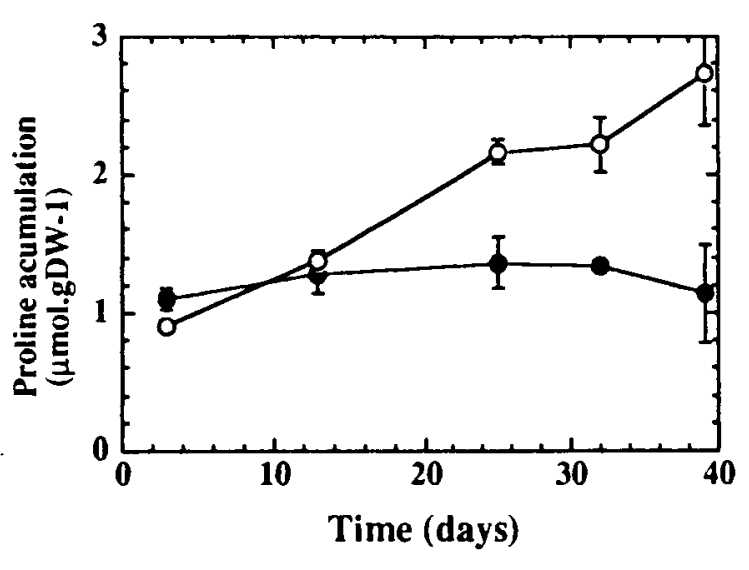

Fig 4. Proline accumulation during drought ( $O$ : water stressed).

lated to an increasing irradiation and vapor pressure deficit (VPD) and also to the higher demand of water due to canopy development. In response to water stress, SLDM progressively increased (15\% increase) until d 32. Leaves sampled after this date showed a dramatic drop to values $13 \%$ lower than control.

The average area of a single leaf (fig $6 \mathrm{~A}$ ) was always smaller in water-stressed plants but the differences between treatments during the first $20 \mathrm{~d}$ of the experiment were lower than $8 \%$. On d 35 smaller mature leaves were apparent as mature leaves at the top of the canopy. These leaves showed a $60 \%$ lower leaf area, while control leaves did not show any important change in leaf size.

The number of leaves per stem (fig 6B), as a good indicator of plant growth, was also clearly affected by soil water depletion after

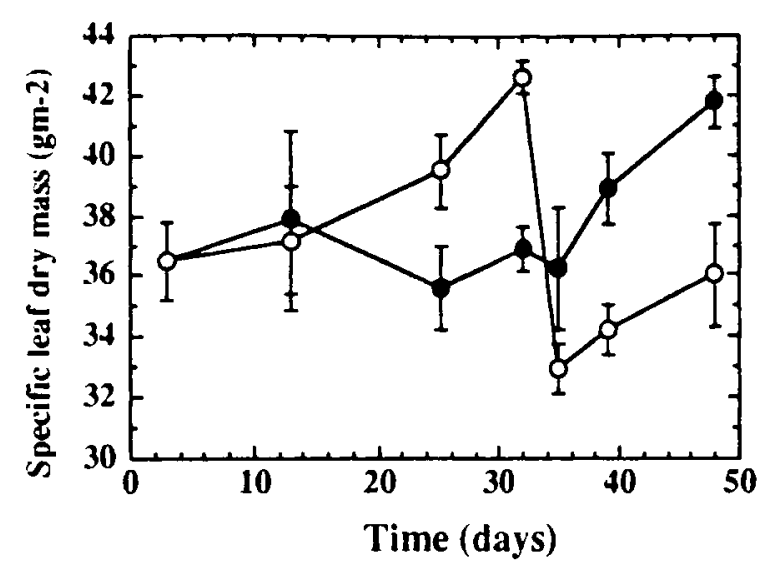

Fig 5. Specific leaf dry mass ( $\bullet$ control; $O$ : water stressed).

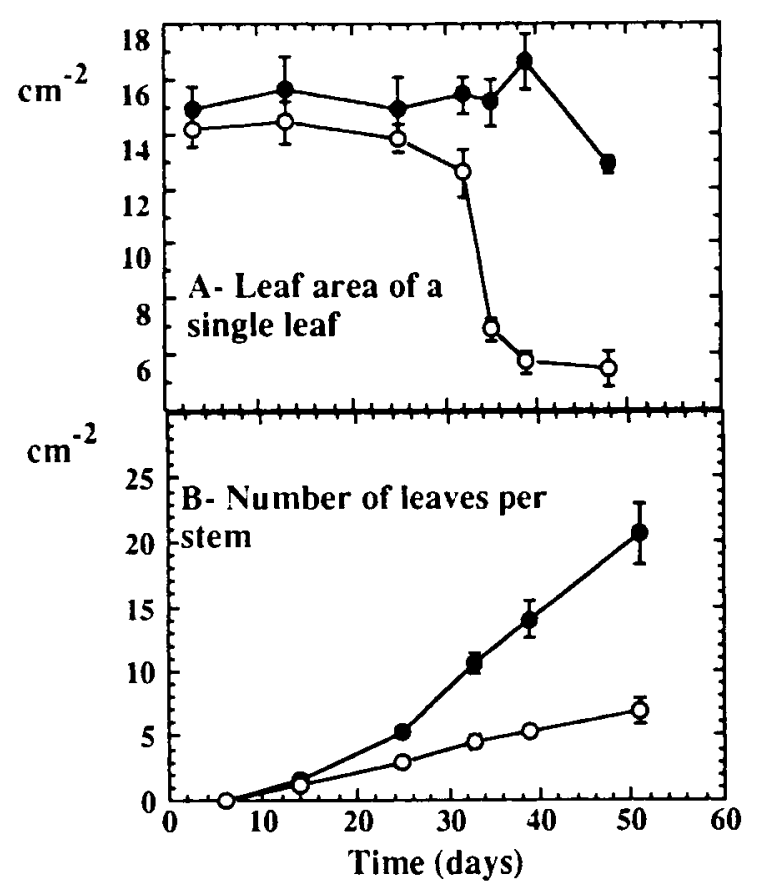

Fig 6. Leaf area of recent fully developed leaf and number of leaves per stem ( : control; $O$ : water stressed).

the first days of the experiment. Leaf appearance rate (the slope of the leaf number versus time) was reduced in water-stressed plants from the first days and maintained rather constant all along the experiment at a rate of 0.13 leaves/d ( $7.5 d$ to the appearance of a new leaf in each stem). Control plants showed progressive increase in this rate until $\mathrm{d} 25$, and then maintained a constant rate of 0.6 leaves/d ( $1.7 \mathrm{~d}$ per new leaf).

\section{Gas-exchange measurements}

Stomatal conductance (fig 7) was gradually reduced in water-stressed plants to very low values (around $0.1 \mathrm{~mol} \mathrm{~m}^{-2} \mathrm{~s}^{-1}$ ) and maintained thereafter at $20 \%$ of control plants. High stomatal conductance was prevalent in control plants throughout the experiment. Similar behavior was detected for transpiration rate (fig 8), where control plants reached very high rates $\left(-10 \mathrm{mmol} \mathrm{m}^{-2} \mathrm{~s}^{-1}\right)$ after an initial increase due to higher atmospheric vapor pressure deficit. In water-stressed plants there was a gradual reduction until $d 25$ followed by a slight increase at the end of the experiment, where a $58 \%$ reduction was maintained in respect to control plants.

The A values in water-stressed plants showed the same course as the $\mathrm{g}$ values (fig 9), 


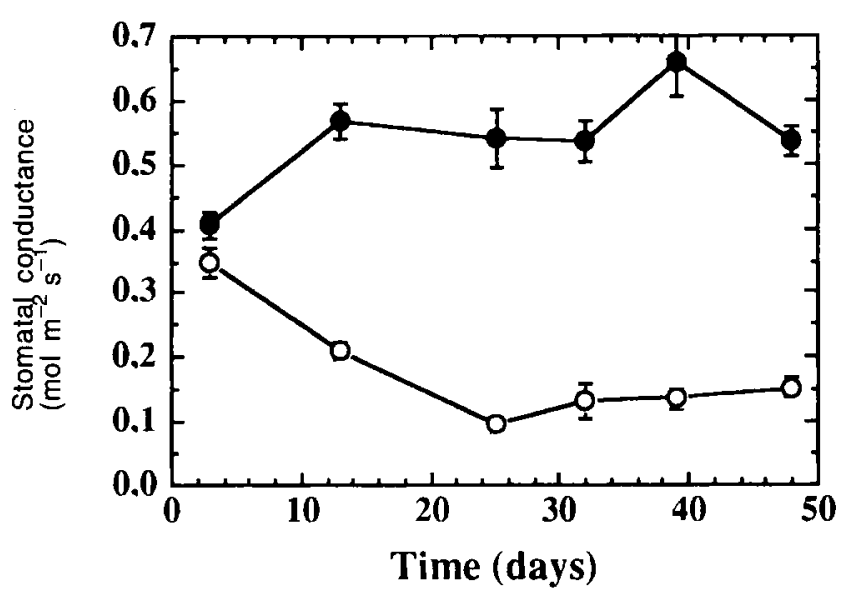

Fig 7. Stomatal conductance (- control; $O$ : water stressed).

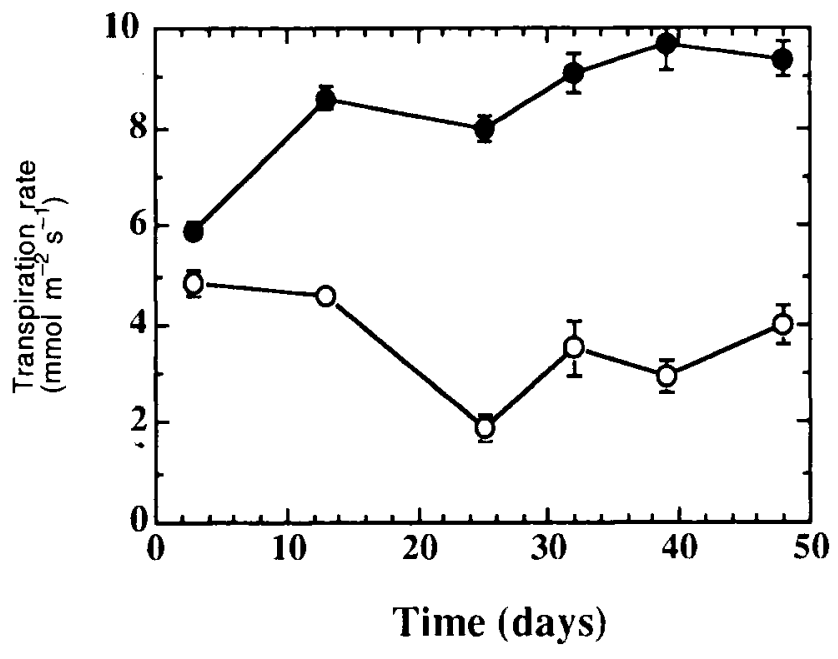

Fig 8. Transpiration rate (- control; $O$ : water stressed).

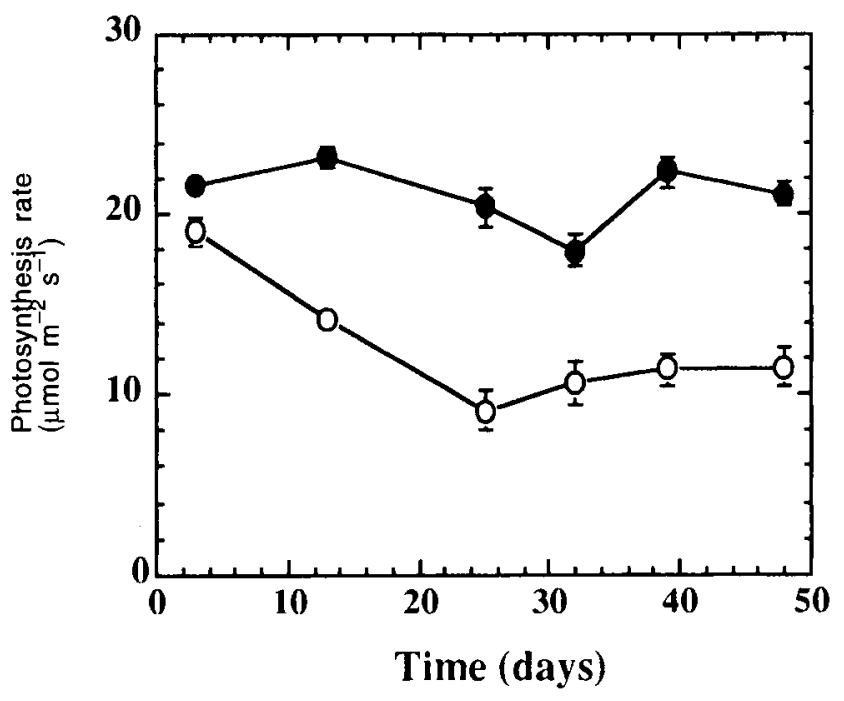

Fig 9. $\mathrm{CO}_{2}$ assimilation rate evolution (- control; $O$ : water stressed). while the $80 \%$ reduction in stomatal conductance at the end of the experiment corresponded to a reduction of only $50 \%$ in assimilation rate.

\section{DISCUSSION}

\section{Soil water depletion and leaf water relationships}

The leaf response to soil water depletion was gradually developed under realistic field conditions representative of most herbage pastures in spring in the Mediterranean area. The general pattern of all water relationship parameters showed a break between the 4th and 5th sampling dates, and took place at the time with the exhaustion of available water in the first $15 \mathrm{~cm}$ of soil profile (fig 1). This dramatic change in leaf water relationships could therefore be understood as an adjustment of the plant to the fall in soil water potential near wilting point (Kramer, 1983). Nevertheless, other leaf characteristics such as leaf size also changed dramatically between these 2 sampling times, and the osmotic potential could have been adjusted in accordance with leaf development previous to wilting point.

Osmotic potential was clearly reduced in water-stressed plants being lower than control from the 3rd sampling. Because high humidity was prevalent on the canopy every night, predawn leaf osmotic potential reductions reflected an osmotic adjustment developed in response to soil water depletioh. Proline accumulation showed a good correspondence with osmotic potential values in water-stressed plants.

In previous experiments (Medrano et al, 1992), when water stress was both gradually and rapidly induced in pot-growing plants, osmotic adjustment was only present for very gradual water-stressed plants under low atmospheric water deficit, and could not be generalized as a plant response to water stress. This finding was in agreement with the lack of osmotic response reported for white clover leaves by Turner (1990). As has been widely demonstrated, the method for imposing water stress determines plant response (Pennypacker 1990), and osmotic adjustment 
has been reported to be very sensitive to the rate at which water stress develops (Morgan 1984, Thomas 1986).

Obviously, the wider and deeper root extension, as well as the clay-calcareous soil allowed a gradual decline in soil water availability for the plant. This could explain the osmotic adjustment obtained under field conditions but not in pots under gradual induced drought. This finding is relevant because of the interest of this character as a selection criteria in genotype screening programs (Ludlow and Muchow, 1990).

\section{Stomatal closure}

Stomatal closure of water-stressed leaves was quickly adjusted to a third of irrigated plant, before any important change in RWC, $\Psi$, or $\Psi_{\pi}$ was detected; the average turgor potential is even a little higher in waterstressed leaves. This quick stomatal closure could be explained by non-hydraulic, chemical signals from dehydrating roots as has been reported by Davies and Zhang (1991). Minimal values of stomatal conductance remained rather constant after d 25. Both $\Psi$ and $\Psi_{\pi}$ showed a dramatic reduction, which led $\Psi_{p}$ to be lower than in control plants. As has been recently demonstrated in field growing plants, the stomatal sensitivity to ABA is also dependent on leaf water status (Tardieu and Davies, 1992, 1993). Nevertheless dramatic drops of $\Psi$ did not correspond with further $\mathrm{g}$ reductions, perhaps because the $\mathrm{g}$ values were already minimal for those leaves.

Reductions in transpiration and photosynthesis were also evident but stabilized at $d 25$ reaching rates of around $50 \%$ of the control leaves. The physiological adjustment developed in response to soil drying allowed an increase in the $A / E$ ratio by around $22 \%$ in soil drying leaves.

\section{Morphological changes}

The most evident change observed as soil water depletion progressed was the appearance of smaller leaves at the top of the canopy. The increase in SLDM and the slight reduction in leaf area recorded in the first weeks, as a first response to water deficit, is commonly described behavior (Lawlor and Leach, 1985). The appearance of those new mature leaves with a smaller size $(60 \%$ reduction) and lower SLDM (13\% less than control) was coincident with the previously described drop in water status. Obviously, those morphological changes achieved by an adjustment of leaf extension in the course of development could not be explained by the dramatic drop in water relations in the last few days before sampling.

Leaf appearance rate was early reduced to $7.5 \mathrm{~d} /$ leaf by soil water depletion. In previous field work with subterranean clover (Vadell, 1991), it was determined that the last fully developed leaf was the 3rd-4th of the stem, so that, according to the leaf appearance rate, the leaves sampled at $d 30$, corresponded to the first group that were under drought from the first phases of leaf development.

In water relations parameters as in morphological ones, the pattern of variation all along the drought period showed a first response of gradual reduction in accordance with a previous description, but, between the 4th and 5th sampling times a dramatic drop was recorded. The most apparent characteristic was the reduction in leaf size, SLDW, and water relationships. It was clearly a new kind of leaf. Nevertheless $g$ and $A$ remained as in the previously sampled group, and $E$ variations were explained by temperature and VPD during measurements.

\section{CONCLUSIONS}

In terms of water economy for the crop, the early $g$ reduction was the most important mechanism of water saving during the first weeks. This stomatal closure was reflected in the evaporation rates of only $25 \%$ of the control, maintained when the A values were near $50 \%$ of irrigated plots. This response was not related to any important change in water relations. When the leaves that were fully developed under drought were sampled, a new decrease in canopy evaporation was achieved by leaf size reduction.

In white clover plants (Turner, 1990), the most important reduction of leaf area in the crop was achieved by early senescence. In the present experiment, although a certain 
leaf senescence was evident, the most generalized morphological responses were the reduction in leaf size and in leaf appearance rate. In a long-term maintained drought these morphological changes are also an important way to reduce water loss.

\section{ACKNOWLEDGEMENT}

The present work is supported by the Plan $\mathrm{Na}$ cional-Inv Agraria, CICYT No AGR89-0729.

\section{REFERENCES}

Bates LS, Waldren RP, Teare ID (1973) Rapid determination of free proline for water-stress studies. Plant soil 39, 205-207

Beadle CL, Ludlow MM, Honeystett JL (1985) Water relations. In: Techniques in Bioproductivity and Photosynthesis ( $\mathrm{J}$ Coombsb, DO Hall, SP Long, JMO Scurlock eds) Pergamon Press, Oxford, 50-61

Dale JE (1988) The control of leaf expansion. Ann Rev Plant Physiol 39, 267-295

Davies WJ, Zhang J (1991) Root signals and the regulation of growth and development of plants in drying soil. Ann Rev Plant Physiol Mol Biol 42, 55-76

Faiz SMA (1983) Use of pressure bomb in the determination of soil water potential. Plant Soil 73, 257-264

Farquhar GD, Sharkey TD (1982) Stomatal conductance and photosynthesis. Annu Rev Plant Physiol 33, 317-345

Gimenez C, Mitchell VJ, Lawlor W (1992) Regulation of photosynthesis rate of two sunflower hybrids under water stress. Plant Physiol 98, 516-524

Kramer PJ (1983) Water relations of plants. Plant, Cell Environ 11, 565-568

Lawlor DW, Leach JE (1985) Leaf growth and water deficits. In: Biochemistry in Relation to Biophysics. Control of Leaf Growth (NR Baker, WJ Davies, CK Ong, eds) Cambridge Univ Press, Cambridge, 267-294

Levitt J (1972) Stress interactions-back to future. Hort Sci 25, 1363-1365
Ludlow MM (1989) Stragegies of response to water stress. In: Structural and Functional Responses to Environmental Stresses (KH Kreeb, $H$ Richter, TM Hinkley eds) Academic publ, the Hague, 269-281

Ludlow MM, Muchow RC (1990) A critical evaluation of traits for improving crop yields in waterlimited environments. Adv Agron 43, 107-153

Medrano H, Aguilo F, Socias FX (1992) Leaf water relations of subterranean clover plants subjected to rapid or slowly induced drought. Photosynthetica 27, 413-419

McGuire WS (1985) Subterranean Clover. In: Clover Science and Technology, USDA Madison, WI

Morgan JA (1984) Osmoregulation and water stress in higher plants. Ann Rev Plant Physiol 35, 299-319

Muslera E, Ratera C (1991) Praderas y forrajes. Producción y aprovechamiento. Ed Mundiprensa, Madrid

Pennypacker BW, Leath KT, Stout WL, Hill RR Jr (1990) Technique for simulating field drought stress in the greenhouse. Agron $J$ 82, 951-957

Sharp RE, Davies WL (1989) Regulation of growth and development of plants growing with a restricted supply of water. In: Plants under stress (HG Jones, TJ Flowers, MB Jones eds). Soc Expt Biol Semin Ser 39, Cambridge Univ Press, Cambridge 71-93

Schulze ED (1986) Whole plant response to drought. J Aust Plant Physiol 13, 127-141

Thomas $H$ (1986) Effect of rate of dehydration of leaf water status and osmotic adjustment in Dactylis glomerata $\mathrm{L}$, Lolium perenne $\mathrm{L}$ and $\mathrm{L}$ multiflorum Lam. Ann Bot 57, 225-235

Tardieu F, Davies WJ (1992) Stomatal response to $A B A$ is a function of current 'plant water status. Plant Physiol 98, 540-545

Tardieu F, Davies WJ (1993) Integration of hydraulic and chemical signalling in the control of stomatal conductance and water status of droughted plants. Plant Cell Environ 16, 341349

Turner LB (1990) The extent of pattern of osmotic ajustment in white clover (Trifolium repens $\mathrm{L}$ ) during development of water stress. Ann Bot $66,721-727$

Vadell J (1991) Variabilitat dels parametres fotosintètics al trèvol subterrani. Doctoral Thesis. Universitat de les lles Balears, Palma de Mallorca, Spain. 